\title{
Periodontal Abscess
}

National Cancer Institute

\section{Source}

National Cancer Institute. Periodontal Abscess. NCI Thesaurus. Code C34917.

An acute purulent bacterial infection that arises from the tissues that surround and support the teeth. 